\title{
Decrease in Activities of Selected Rat Liver Enzymes following Consumption of Chemical Effluent
}

\author{
OLOYEDE, O. B.; *SUNMONU, T. O.
}

Department of Biochemistry, University of Ilorin, Ilorin, Nigeria.+2348033939464.E-mail: taosun77@yahoo.com

\begin{abstract}
The effects of the chemical effluent from Soap and Detergent Industry on some rat liver enzymes were investigated. Chemical analyses of both the effluent and tap water which served as the control were carried out before various concentrations of the effluent $(5 \% \mathrm{v} / \mathrm{v}, 25 \% \mathrm{v} / \mathrm{v}, 50 \% \mathrm{v} / \mathrm{v}$ and $100 \% \mathrm{v} / \mathrm{v})$ were made. The effluent as collected from source represents $100 \% \mathrm{v} / \mathrm{v}$. Four groups of five (5) rats each were placed on the four concentrations of the effluent prepared as the only source of water for thirty (30) days. The rats in the fifth group which served as the control were placed on tap water for the same period of time. All the rats were maintained on commercial rat chow for the duration of the experiment. At the end of the experiment, the animals were sacrificed and blood samples were collected. The effect of the chemical effluent on rat liver was monitored by conducting standard enzyme assays for alkaline phosphatase (ALP), alanine transaminase (ALT), aspartate transaminase (AST) and lactate dehydrogenase (LDH) in the liver and serum of experimental animals. Relative to the control, significant $(\mathrm{p}<0.05)$ decrease in the activity of the liver enzymes and significant $(\mathrm{p}<0.05)$ increase in the activity of the serum enzymes studied were observed in all the test rats with the effect most significant in the $100 \% \mathrm{v} / \mathrm{v}$ group of rats. On the whole, chemical effluent from Soaps and Detergent Industry may impair liver function and could pollute any river that serves as a recipient to it. @ JASEM
\end{abstract}

Industrial activities especially food processing and chemical manufacturing industries generate a wide variety of waste products that may be discharged into flowing waters. Some of these wastes are known to be poisonous to man, animals and plants, while the effects of the others are obscure (Alloway and Ayres, 1997). Industrial waste disposal is the principal cause of water pollution. Many industrial wastes are organic compounds that can be degraded by bacteria but only very slowly so that they may carry unpleasant odour and taste along a water course for considerable distances. To complicate matters, some of these wastes react with the chlorine that is used to purify water. The result of such reaction is the production of chlorinated organic compounds whose smell and taste are worse than the original waste products. Polluted water may be unsightly, odorous, corrosive or unpleasant to taste (Lee and Jones-Lee, 1993). But certainly, the most harmful effect of polluted water on man has been that of diseases. Thus, if water polluted by microorganisms is consumed, diseases such as typhoid fever and cholera can result. Other human diseases caused by microorganisms in water are dysentery, hepatitis and gastroenteritis. Most organics derived from industries are decomposed in water by bacteria, protozoan and various larger organisms (Johansen and Carlson, 1999). Such decomposition converts energy-rich substances to energy-poor ones by chemical reactions that utilize oxygen. The oxygen soon becomes exhausted and thus becomes unavailable for other forms of life such as fish which man prefers to eat. Finally, stinks of putrefaction set in (Lee and Jones-Lee, 1994).

Analysis of industrial effluents by various researchers has shown that it contains many organic and inorganic substances which are dangerous to health (Cherry, 1990; Oloyede et al.,
2003). However, the biochemical consequence of the consumption of these pollutants especially on rat liver has not been extensively studied. In the present study, an attempt is made to assess the effects of chemical effluent from Soap and Detergent Industry on rat liver using enzymes as bio-indicators. The choice of the effluent was informed by the fact that it drains into an adjoining river thus making water from the river unfit for domestic and recreational purposes (Oloyede et al., 2003).

\section{MATERIALS AND METHODS} Chemicals and Reagents

All chemicals and reagents used in this study were of analytical grades.

\section{Industrial effluent and tap water}

The effluent used in this study was obtained from a Soap and Detergent Industry. The effluent was collected directly from the outlet tap of the company and was designated $100 \% \mathrm{v} / \mathrm{v}$ concentrated effluent. Tap water was collected once at the University of Ilorin Conference Center. Appropriate volume of the effluent was diluted using tap water to obtain various concentrations as indicated in Table 1.

Table 1: Preparation of various concentrations of chemical effluent

\begin{tabular}{llll}
\hline $\begin{array}{l}\text { Concentrations } \\
(\% \mathrm{v} / \mathrm{v})\end{array}$ & $\begin{array}{l}\text { Global } \\
\text { effluent }(\mathrm{ml})\end{array}$ & $\begin{array}{l}\text { Tap water } \\
(\mathrm{ml})\end{array}$ & $\begin{array}{l}\text { Total } \\
\text { volume }(\mathrm{ml})\end{array}$ \\
\hline Control & 0 & 100 & 100 \\
5 & 5 & 95 & 100 \\
25 & 25 & 75 & 100 \\
50 & 50 & 50 & 100 \\
\hline 100 & 100 & 0 & 100 \\
\hline
\end{tabular}




\section{Experimental animals}

Twenty five albino rats (Rattus norvegicus) with a mean weight of $42.2 \pm 2.05$ were obtained from the Small Animal Holding Unit of the Department of Biochemistry, University of Ilorin, Ilorin, Nigeria. The animals were grouped into five with each group containing five rats. The group detail is as follows:

Group 1 (control): Rats given tap water as the only source of water for thirty days;

Group $2(5 \% \mathrm{v} / \mathrm{v})$ : Rats given $5 \% \mathrm{v} / \mathrm{v}$ concentrated chemical effluent as the only source of water for thirty days;

Group $3(25 \% \mathrm{v} / \mathrm{v})$ : Rats given $25 \% \mathrm{v} / \mathrm{v}$ concentrated chemical effluent as the only source of water for thirty days;

Group $4(50 \% \mathrm{v} / \mathrm{v})$ : Rats given $50 \% \mathrm{v} / \mathrm{v}$ concentrated chemical effluent as the only source of water for thirty days;

Group $5(100 \% \mathrm{v} / \mathrm{v})$ : Rats given $100 \% \mathrm{v} / \mathrm{v}$ concentrated chemical effluent as the only source of water for thirty days.

The animals were housed in metabolic cages and fed ad libitum with commercial rat chow for a period of thirty days which was preceded by five days of acclimatization. The mean weight of the animals in each group was taken at five days interval.

\section{Physicochemical properties of effluent and tap water}

The physicochemical characteristics of the chemical effluent and tap water used as control were analyzed in accordance with standard methods (APHA, 1985). Heavy metals including $\mathrm{Pb}, \mathrm{Cd}, \mathrm{Mn}, \mathrm{Cu}$ and $\mathrm{Fe}$ were determined using Atomic Absorption Spectrophotometer Perkin Elmer model 406 based on standard methods as described by APHA (1985).

\section{Collection of blood sample and preparation of liver homogenate}

At the expiration of 30 days, the animals were sacrificed. Blood samples were quickly collected and immediately spinned using a centrifuge at $500 \mathrm{~g}$ for $5 \mathrm{~min}$ for serum collection. After dissection, the liver was quickly excised and transferred into a test tube containing $0.25 \mathrm{M}$ ice cold sucrose solution. A known weight of the liver was thereafter homogenized in ice-cold $0.25 \mathrm{M}$ sucrose solution using pestle and mortar.

\section{Enzyme assay}

Total protein in the liver was determined according to the method of Henry et al. (1974). Alkaline phosphatase (ALP) activity was determined using the method of Wright et al. (1972). Activities of aspartate transaminase (AST) and alanine transaminase (ALT) were determined based on the method described by Schmidt and Schmidt (1963). The method of Wrebleski and La Due (1975) was employed for the assay of lactate dehydrogenase (LDH).

\section{RESULTS AND DISCUSSION}

The physicochemical characteristics of the effluent, tap water and World Health Organization (WHO) standard for drinking water are presented in Table 2. The data revealed that the $\mathrm{pH}$ of the effluent is acidic and this may be attributed to presence of acid used in the production of detergent. The $\mathrm{pH}$ value obtained for the effluent is outside the WHO recommendation for drinking water which made the effluent potentially hazardous especially if it drains into a nearby river (Oloyede et al, 2003). Biochemical Oxygen Demand (BOD) and Chemical Oxygen Demand (COD) of the Global effluent are also higher than the WHO recommendation for drinking water. This probably accounts for the odorous nature of the effluent as submitted by Lee and Jones-Lee (1993) that BOD and COD are responsible for the taste and odour of water. However, levels of the heavy metals determined in the effluent fell within safety range as prescribed by WHO. As a result, heavy metal toxicity may not result from consumption of the effluent under consideration. Other parameters determined in the effluent compared favourably with that of tap water.

Table 2: Physicochemical characteristics of chemical effluent,

\begin{tabular}{lllll}
\multicolumn{5}{c}{ tap water and WHO standards } \\
\hline Parameters & $\begin{array}{c}\text { Tap water } \\
(\mathrm{mg} / \mathrm{l})\end{array}$ & $\begin{array}{l}\text { Global } \\
\text { effluent }(\mathrm{mg} / \mathrm{l})\end{array}$ & $\begin{array}{c}\text { *WHO } \\
\text { RMC }\end{array}$ & MPC \\
\hline $\mathrm{pH}^{\#}$ & 7.8 & 5.0 & $7-8$ & $\mathrm{ND}$ \\
$\mathrm{BOD}$ & $\mathrm{ND}$ & 1.24 & $\mathrm{ND}$ & $\mathrm{ND}$ \\
$\mathrm{COD}$ & $\mathrm{ND}$ & 1.98 & $\mathrm{ND}$ & $\mathrm{ND}$ \\
Total solids & 340.2 & 240.0 & 500 & 1500 \\
Total diss. Solids & 153.0 & 139.0 & $\mathrm{ND}$ & $\mathrm{ND}$ \\
Nitrate & 0.06 & 5.14 & $\mathrm{ND}$ & $50-100$ \\
Lead & $<0.05$ & $<0.05$ & $\mathrm{ND}$ & 0.1 \\
Cadmium & $<0.002$ & $<0.002$ & $\mathrm{ND}$ & $\mathrm{ND}$ \\
Manganese & 0.04 & 0.351 & 0.1 & 0.5 \\
Copper & $<0.002$ & $<0.002$ & 1.0 & 1.5 \\
\hline Iron & 0.001 & 0.464 & 0.3 & 1.3 \\
\hline
\end{tabular}

${ }^{\#}$ Not in $\mathrm{mg} / \mathrm{l}$

$\mathrm{RMC}=$ Recommended maximum concentration

$\mathrm{MPC}=$ Maximum permissible concentration

$\mathrm{ND}=$ Not detectable

* Source: US. Environmental Protection Agency (1973). 


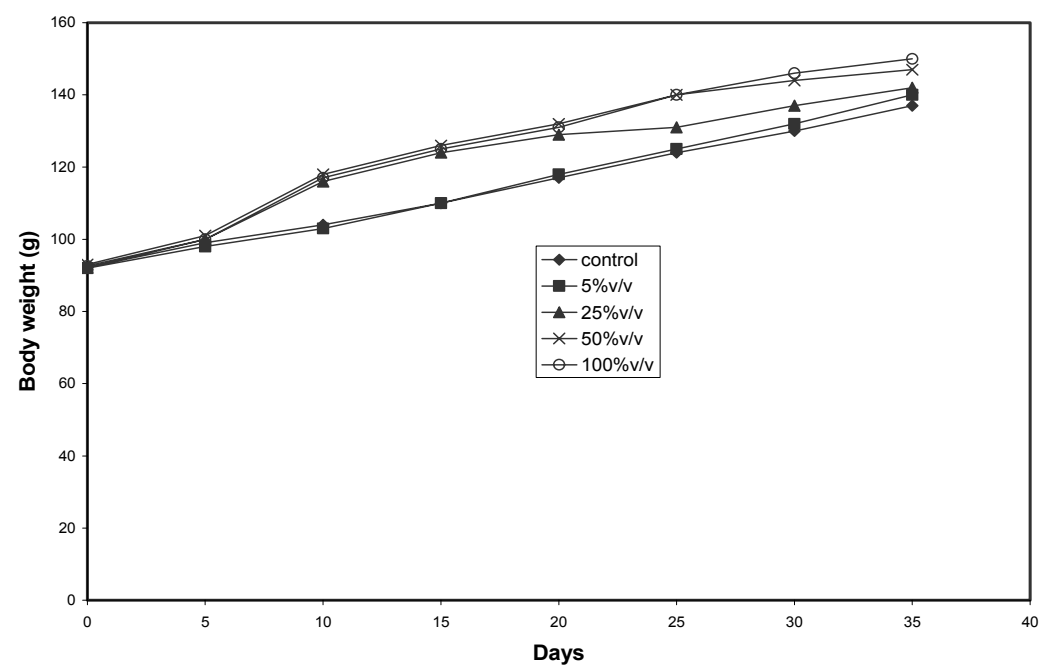

Fig. 1: Growth response curve of rats placed on various concentrations of chemical effluent. There is no significant difference $(\mathrm{p}<0.05)$ among the various growth curves.

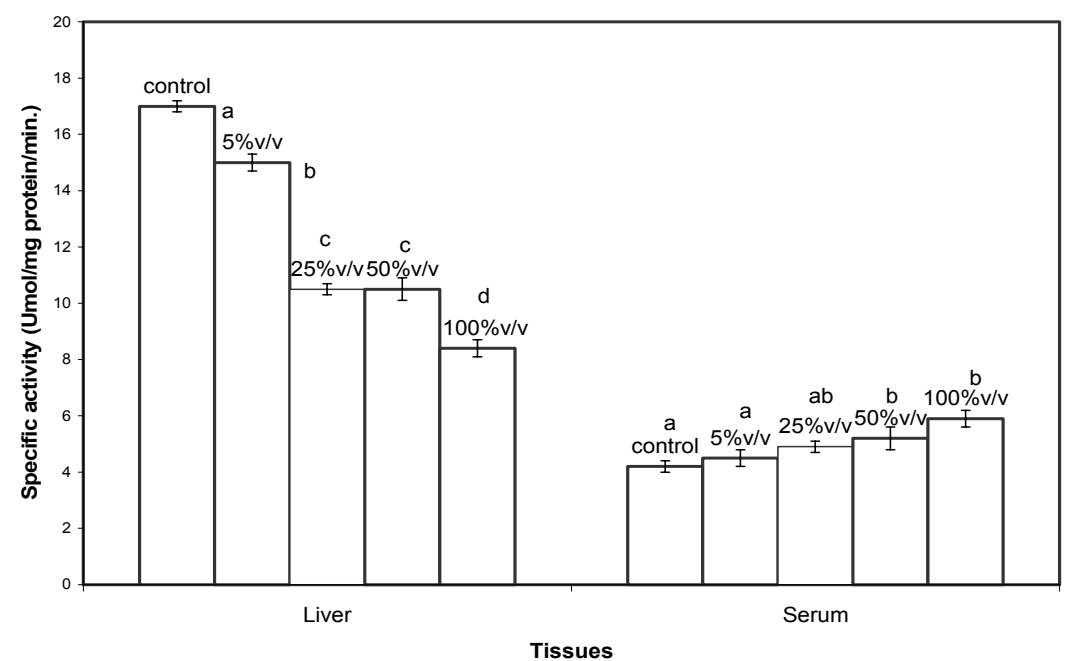

Fig. 2: Specific activity of alkaline phosphatase in the liver and serum of rats placed on various concentrations of chemical effluent. Results are mean of five determinations \pm S.E.M. Bars carrying different letters are significantly different $(\mathrm{p}<0.05)$.

Fig. 1 represents the growth response curve of rats placed on various concentrations of the chemical effluent over a period of thirty days. All the animals increased in weight significantly $(p<0.05)$ after thirty days relative to their initial weight at the beginning of the experiment. Also, final weight of the animals in each group showed no significant difference $(p<0.05)$ relative to one another and relative to the control. This observation compared favourably with the observation of Oloyede et al. (2003) which revealed that polluted water supports growth in rats. Bakare et al (1999) also reported a better growth response for Allium cepa grown in an environment covered by polluted water than those grown on tap water.

Measurement of activities of various enzymes in tissues and body fluids is a significant and well known aid in disease investigation and diagnosis (Malomo, 2000). Such measurement will give an insight to the site of cellular damage as a result of assault by drugs or other chemicals. The measurement of enzyme activity is particularly important because it sums up the catalytic influence of various factors like inhibitors and activators during such pathological conditions. The specific activity of alkaline phosphatase (ALP) in the liver and serum of rats placed on various concentrations of the chemical effluent is presented in Fig. 2. Relative to the control, there was a significant reduction $(\mathrm{p}<0.05)$ in ALP activity as the concentration of the effluent increased. The decrease was most significant $(\mathrm{p}<0.05)$ at $100 \% \mathrm{v} / \mathrm{v}$ concentration. However, there was a compensating increase in serum ALP as the concentration of the 
effluent increased. Similarly, the increase was most significant $(\mathrm{p}<0.05)$ at $100 \% \mathrm{v} / \mathrm{v}$ concentration. The reduction in the liver ALP as the concentration of the effluent increased may partly be due to alteration in the liver cellular system which results in enzyme leakage into the serum. Moreover, ALP is a marker enzyme for the plasma membrane and endoplasmic reticulum, therefore, damage to membranes of tissues may affect ALP activity. The effluent may also contain substances which are capable of inhibiting or inactivating ALP in situ (Umezawa and Hooper, 1982). The reduction in ALP activity could also be due to inhibition as it is the case with the consumption of polluted Asa water (Oloyede et al., 2003) or metabisulphite (Akanji et al, 1993). The significant increase $(p<0.05)$ in the activity of ALP in the serum of experimental rats as the concentration of effluent increased may be associated with possible leakage of the enzyme from the liver into the serum. Normally, enzyme will not always be found in the serum except there is damage to one or more organs or tissues of the body. Therefore, enzymes from diseased tissues or organs (e.g. cardiac, hepatic and neoplastic diseases) and from drug assault or other xenobiotics may become manifested in the serum resulting in increased activity since they must have leaked from the diseased tissue. Increased activity of serum enzymes have been reported in conditions of tissue damage due to such disease conditions and from the use of several chemicals and drugs (Hanley et $a l .$, 1986). This is often accompanied by a corresponding decrease in enzyme activity in the effected tissues or organs.

The specific activity of aspartate transaminase (AST) in the liver and serum of rats placed on various concentrations of the chemical effluent is presented in Fig. 3. There was a significant $(\mathrm{p}<0.05)$ reduction of AST activity in the liver, and a significant $(p<0.05)$ increase in serum AST activity, as the concentration of the effluent increased. Similarly, the activity of alanine transaminase $(A L T)$ reduced significantly $(p<0.05)$ in the liver and increased significantly $(p<0.05)$ in the serum as the concentration of the effluent increased (Fig. 4). The decrease in the liver AST and ALT followed by concomitant increase in serum AST and ALT suggests that there may be a leakage of these enzymes from the liver to the serum. It is well known that the transaminases play a paramount role in amino acid metabolism and in providing necessary intermediates for gluconeogenensis. It has also been reported that these enzymes assist in differential diagnosis of cardiac diseases (Schmidt and Schmidt, 1963). The decrease in the specific activity of AST and ALT of the liver and the significant increase in activities of the two enzymes in the serum suggest that there may be a leakage of the enzymes from the liver to the serum which may be interpreted to mean damage to the liver (Hanley et al., 1986). Fig. 5 presents the specific activity of lactate dehydrogenase (LDH) in the liver and serum of rats placed on various concentrations of the chemical effluent. There was significant difference $(p<0.05)$ between each groups of rats relative to the control. In the liver of control rats, LDH activity was significantly higher $(p<0.05)$ than that of any of the test group of rats. Conversely, serum LDH activity was significantly $(\mathrm{p}<0.05)$ lower in the control than any of the test groups. It follows from this observation that LDH may be leaking to the serum, an indication of hepatocyte damage.

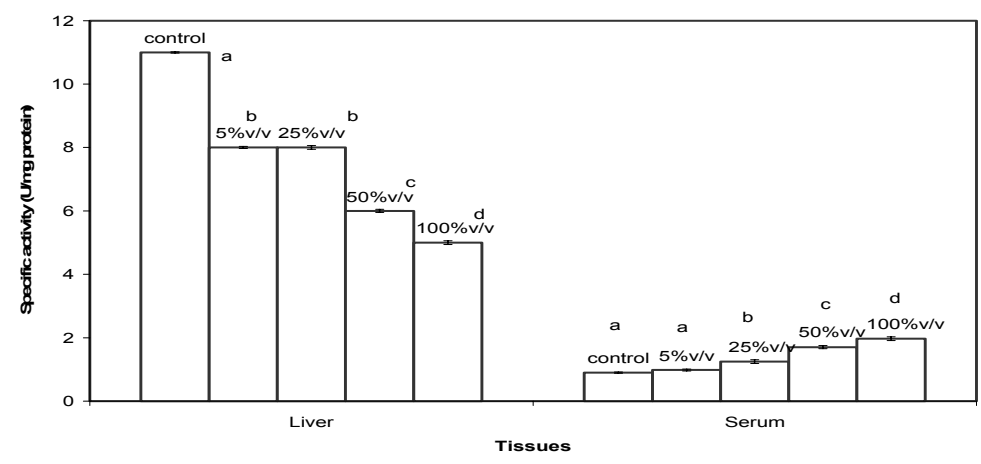

Fig. 3: Specific activity of aspartate transaminase in the liver and serum of rats placed on various concentrations of chemical effluent. Results are mean of five determinations \pm S.E.M. Bars carrying different letters are significantly different $(\mathrm{p}<0.05)$. 


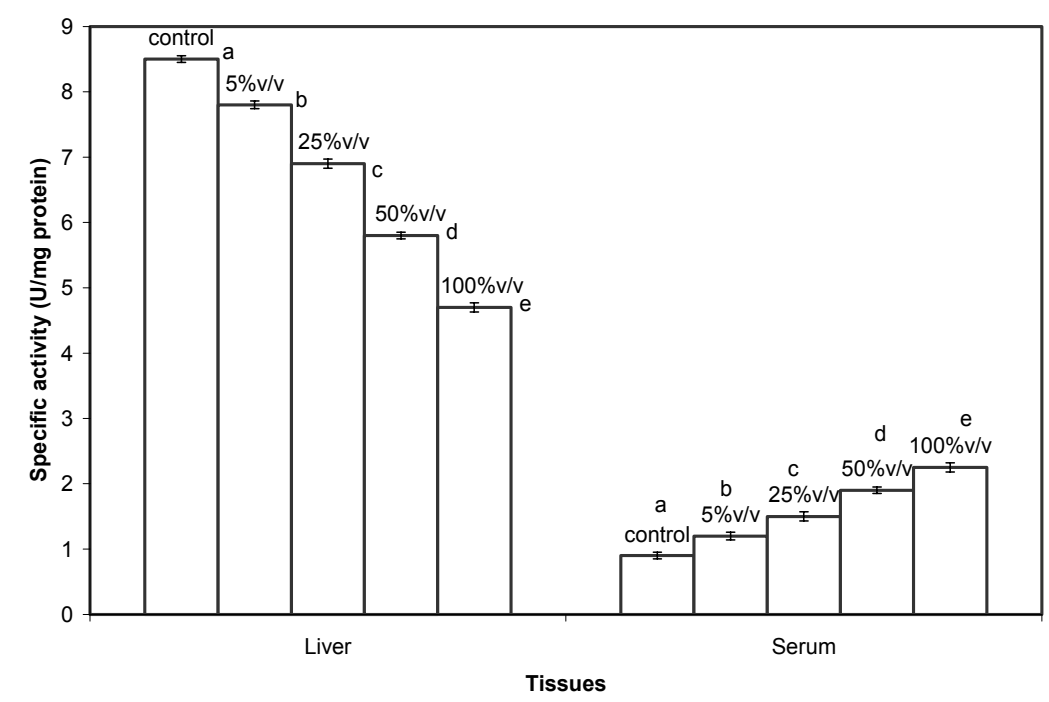

Fig. 4: Specific activity of alanine transaminase in the liver and serum of rats placed on various concentrations of chemical effluent. Results are mean of five determinations \pm S.E.M. Bars carrying different letters are significantly different $(\mathrm{p}<0.05)$.

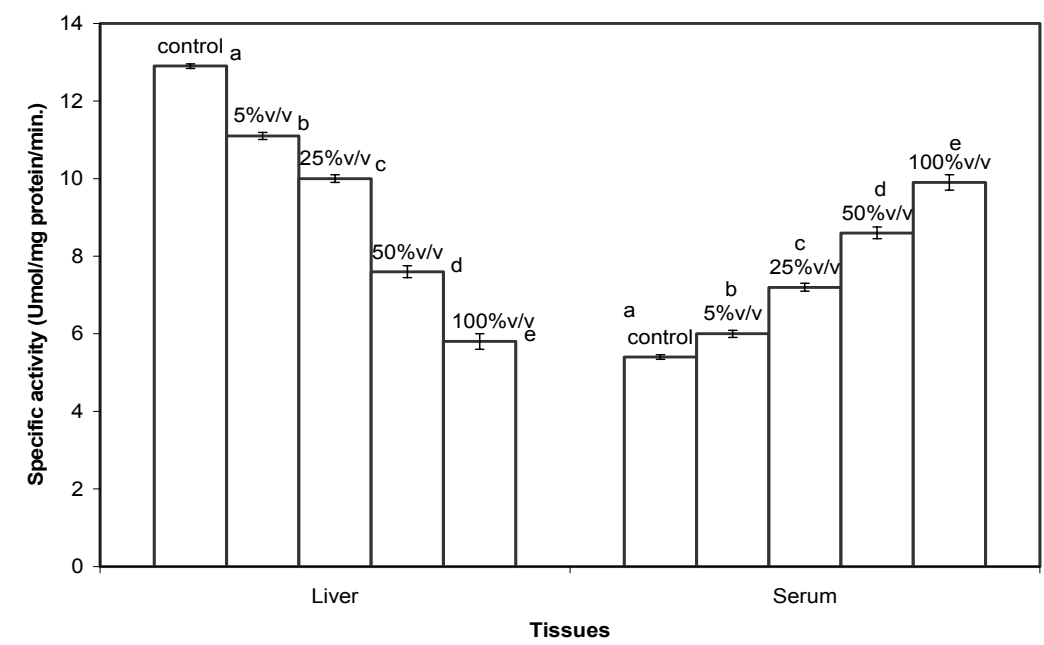

Fig. 5: Specific activity of lactate dehydrogenase in the liver and serum of rats placed on various concentrations of chemical effluent. Results are mean of five determinations \pm S.E.M. Bars carrying different letters are significantly different $(\mathrm{p}<0.05)$.

\section{Conclusion}

The present study has shown that chemical effluent has a high potential of polluting drinking water especially when one considers the myriad of effects it has on the liver. Consumption of such effluent either directly or indirectly as a component of drinking water may result in liver damage and as such should be avoided.

\section{REFERENCES}

Akanji, MA; Olagoke, OA; Oloyede, OB (1993).

Effect of chronic consumption of metabisulphite on the integrity of rat liver cellular system. Toxicol. 81, 173-179.
Alloway, BJ; Ayres, DC (1997). Chemical principles of environmental pollution. $2^{\text {nd }} \mathrm{Ed}$. pp. 353-358.

APHA (1985). Standard methods for examination of water and waste water. American Public Health Association, $16^{\text {th }}$ edition, Washington.

Bakare, AA; Mosuro, AA; Osibanjo, O (1999). Cytotoxic effect of landfill leachate toxicity. Water Res. 17(12) 1855-1861.

Cherry, J (1990). "Groundwater monitoring" some differences and opportunities in: Hazardous waste site investigation, towards better 
decisions. Proc. $10^{\text {th }}$ ORNL Life Sciences Symposium Gathering.

Hanley, KS; Schmidt, E; Schmidt, FM (1986). Enzymes in serum, their volumes in diagnosis, pp 79 - 81. Charles Thomas Springfield, Illinois.

Henry, RJ; Cannon, DC; Winkleman, JW (1974). Clinical Chemistry, Principles and techniques. Harper and Row, $2^{\text {nd }}$ edn.

Johansen, OJ; Carlson, OH (1976). Characteristics of sanitary landfill leachates. Water Res. 10: 1129-1134.

Lee, GF; Jones-Lee, A (1993). Landfills and groundwater pollution issue. Dry tomb vs $\mathrm{F} / \mathrm{L}$ wet cell landfills. Proc. Sardinian '93 IV National Landfill Symposium. S. Margherita dipula, Italy.

Lee, GF; Jones-Lee, A (1994). "Dry Tomb" Landfill MSW Management. 6(1): 82-89.
Malomo, SO (2000). Toxicological implications of ceftriaxone administration in rats. NJBMB 15 (1): 33-38.

Oloyede, OB; Sunmonu, TO; Adeyemi, O; Bakare, AA (2003). Biochemical assessment of the effect of polluted water from Asa River in rat kidney. NJBMB. 18.: 25 -32.

Schmidt, E; Schmidt, FW (1963). Determination of serum GOT and GPT. Enzym. Biol. Clin. 3:1

Umezawa, H; Hooper, JR (1982). Aminoglycosides antibiotics. Spanger Verki, Berlin, Hadelberg. New York. $1^{\text {st }}$ Ed. pp 1-20.

USEPA (1973). Proposed criteria for water quality. Vol. 1. Washington D.C.

Wright, PJ; Leattwood, AA; Plummer, DT (1972). Enzymes in rat urine; Alkaline phosphatase. Enzymologia. 42:317-327.

Wroblewski, F; La Due, JS (1975). LDH activity in the blood. Proc. Soc. Exp. Biomed. 90: 210215 . 